\title{
Rural Nonfarm Activity Income Diversification Among Smallholder Farmers in Deber Elias Woreda, Amhara Regional State, Ethiopia
}

\author{
Mezegbu Aynalem , Habtamu Mossie ${ }^{2, *}$, Mohammed Adem ${ }^{3}$ \\ ${ }^{1}$ Department of Agree Business and Value Chain Management, Debermarkos University Burie, Campaus, DebreMarkos, Ethieopia \\ ${ }^{2}$ Department of Agricultural Economics, Wolikte University College of Agriculture and Natural, Wolikte, Ethiopia \\ ${ }^{3}$ Department of Economics, College of Business and Economics, Samara University, Samara, Ethiopia \\ Email address: \\ mezgebu12aynalem@gmail.com (M. Aynalem), habtamu.elias7@gmail.com (H. Mossie), mameyaadem@gmail.com (M. Adem) \\ ${ }^{*}$ Corresponding author
}

\section{To cite this article:}

Mezegbu Aynalem, Habtamu Mossie, Mohammed Adem. Rural Nonfarm Activity Income Diversification Among Smallholder Farmers in Deber Elias Woreda, Amhara Regional State, Ethiopia. American Journal of Environmental and Resource Economics.

Vol. 4, No. 2, 2019, pp. 84-91. doi: 10.11648/j.ajere.20190402.15

Received: March 14, 2019; Accepted: June 11, 2019; Published: July 12, 2019

\begin{abstract}
This research was carried out with the aim examining and understanding the different nonfarm diversification strategies pursued by households in Deber Elias Woreda. A multi stage sampling procedure was employed to select 120 households. First the Woreda Kebeles are stratified in to three categories based on the agro ecology. From each stratum, three sample target kebeles and respective villages selected for primary or secondary data collection. Descriptive statistics and binary logit model were used. Narration was used to analyze the qualitative data. The income portfolio analysis revealed that agriculture is the main livelihood activity in the study area contributing $86.9 \%$ and nonfarm activity income which accounts for $5.7 \%$ the remaining $2.3 \%$ share of the total income. Only $40.8 \%$ of the sample respondents participate in nonfarm diversification activities. Regarding the participants in diverse nonfarm activities in the study area female-headed households diversified more than male-headed households, better offs diversified more than poor, educated households diversified better than illiterates and households with large number of family members more diversified than those with small household size. The binary logit model result for determinants of nonfarm activity diversification reveals that sex of household head, educational status of household head, credit access; landholdings of households and household size were statistically significant. Finally, this thesis indicates the important policy implications suggesting that programs, projects and/or any interventions designed targeting to engage people in other income generating activities in Debre Elias woreda.
\end{abstract}

Keywords: Diversification, Income, Nonfarm Activity, Non-participants and Participants

\section{Introduction}

Agriculture is the basic economic sector on which the country relies for its social and economic development. Its contribution to the gross domestic product (GDP), employment, and foreign exchange earnings of the country is about 35.8, 72.7 and 90 percent, respectively, makes it the incontestable sector in the country's development prospect [1] Despite its importance, the production and productivity of the sector still remains very low as of the traditional, subsistence and nature dependent nature of its production systems. Developing nation's agriculture is mainly dependent on environment and natural resource. So it is highly exposed to risk. Small-scale farmers in developing nations then tend to diversify their income to diversify risk and to cope up hazards. The landholding per household is diminishing through time and people in these areas also thinking another means of lives. The poor are observed to diversify income sources in order to cope with risk, seasonality and other adverse factors in agriculture, but almost no recognition has been given to this behavior by the policy processes previously unfolding in low income countries [2]. Policy makers thus should think diversification specially nonfarm 
activity diversification when thinking rural development because rural development can no longer be based only on traditional agricultural activities, permanently restricted to risk, the uncertainty and impoverishment factors of production [3].

Recognizing this fact it is essential for the smallholder farmers to involve in other income earning activities, besides attempting to improve production and productivity of agriculture. For instance, Dimova and Sen [4] stated that participation and specialization of smallholder farmers in one particular activity is the exception and income diversification through participating in different activities is a custom. This is due to the fact that income diversification could help small-holders farmers to address the problem of risks and uncertainties, [5]; Dimova and Sen [4] that their farming, which is nature dependent and rain-fed agriculture, usually encountered and also expected to create higher income [6]. Being agriculture is nature dependent and the common jobs of small- holder farmers, it is usually characterized by different problems such as poor soil fertility, volatile rainfall, crop and livestock diseases, price shocks for crop and livestock products and other related conditions which guide to generating low income and gradually leads to food insecurity and poverty.

Agricultural production becomes low due to crop or livestock failures resulting from agro - climatic shocks and/or market failures, farm households utilize non- farm incomes to stabilize aggregate income flows and secure food access. In addition, they use non- farm income in the crucial hungry period between food stores running out and the next harvest season [7]. This implies that non-farm income cannot only be used as a mechanism to stabilize the household income but also reduces early harvest consumption or distress selling at early harvest time. Under scarce land and imperfect land market it also enables to create more job opportunity for some rural household members (mainly youths and women who are victims of this problem) and this contributes for the reduction of rural unemployment. In Ethiopia, where income from farm activities varies considerably, farm households usually engage in non- farm activities to supplementtheir agricultural income [8]. Hence, non-farm income is expected to enhance their production and productivity of farming.

However, it is not well known whether there exists variability in the level of income diversification among rural farm households in the study areas. Besides, some rural households in the study area allocate their working time between farms and non-farm activities to have secure income (consumption) for their family members while others engaged in farming only. Yet, it is not clear why some households engage only in farm activities while others engage in both farm and non-farm income generating activities. Non-farm employment provides additional income that enables farmers to spend more on their basic needs include food, education, closing and health care. This implies that non-farm employment has a significant role in maintaining household food security [9]; [10]; [11]. This shows that there is a gap in rural households to diversify their income sources assisting to smooth their consumption all round the year in the study area. Therefore, the purpose of this study is to assess the main nonfarm activity diversification strategy, in Deber Elias Woreda as well as it identifies which part of the community more participate in nonfarm activity diversification.

\section{Methodology}

\subsection{Description of the Study Area}

Debre Elias woreda is one of the eighteen woreda, which found in East Gojjam Zone, Amhara Regional state of Ethiopia, which is located around $340 \mathrm{~km}$ Northwest of Addis Ababa and about $41 \mathrm{~km}$ Northwest of DebreMarkos town. It bounded by the Abay River at the south and west, West Gojjam Zone at the northwest, Machakeleworeda at the north, and Gozamenworeda at the east. In the study woreda there are sixteen Kebele administrations (KAs) with one urban kebele and fifteen rural kebeles. From the total sixteen KAs in the study woreda, three rural kebeles namely Guayi, Gofichema and Yikgat were the study sites. The altitude of the woreda ranges from 800-2200 meter above sea level (m.a.s.1.) and receives mean annual rainfall of $1150 \mathrm{~mm}$, which occurs mainly in the June, July, August and September. Other months of the year are almost dry with erratic rainfall. The average daily temperature ranges from $18-27^{\circ} \mathrm{C}[12]$.

\subsection{Sampling Procedure and Sample Size}

Multistage sampling is used to select sample kebeles and to select respondents in those kebeles. It is because of sample respondents were selected stage by stage after sample Kebeles and villages are selected. The first step was the selection of three kebeles from the Woreda. The reason for the classification of the Woreda based on their agroecological zone and cluster is to get the most representative data of the Woreda. Households in one agro-ecological zone and cluster are assumed to be homogenous. Once the kebeles are stratified based on their agro-ecological zone and their cluster, then one Kebele (Guayi) from lowland, one from midland (Goffichma) and one Kebele from semi midland (Yikgat) agro-ecological region selected randomly. Having selected kebeles from each agro-ecological zone, then the villages in the respective kebeles are listed down and one village from each Kebele chosen randomly. Then the sampling frame was made available from the respective Kebele manager. Lastly 120 households selected in simple randomly technique $40 \mathrm{HH}$ heads from each village. These 120 sample HHs are taken by using pennstate cooperative extension sampling technique as stated below

An Equation for Determining Final Sample Size

$$
\mathrm{n}=\frac{\frac{1-p}{Z} \frac{A^{2}+\frac{p(1-p)}{N}}{R}}{R}
$$

Where 
$\mathrm{n}=$ number of sample required

$\mathrm{P}=$ Estimated variance in population, as decimal (i.e. 0.03 , $0.05,0.01$ for $3 \%, 5 \%, 10 \%$

$\mathrm{N}=$ number of population

$\mathrm{A}=$ Precisiondesired, expressedasadecimal (i.e., 0.03, 0.05, 0.1 for $3 \%, 5 \%, 10 \%$ )

$\mathrm{Z}=$ based on confidence level: 1.96 for $95 \%$ confidence, 1.6449 for $90 \%$ and 2.5758 for $99 \%$

$\mathrm{R}=$ Estimated Response rate, as decimal

\subsection{Methods of Data Collection}

Both semi-structured questionnaire for household survey and checklists for key-informant interviews and FGDs are used. Focus group desiccation and key-informant interviews to get in depth information on the livelihood of the population, the nonfarm activity in the area constraints of participation in nonfarm activity, economic, political, and socio-cultural information of the households on the area. Checklist used to protect missing of points. These questions prepared first in English and then translate into Amharic.

\subsection{Method of Data Analysis}

Two types of data analyses, namely descriptive statistics and econometric analysis were used for analyzing the data collected from the respondent in the study areas. Quantitative data was analyzed by descriptive and inferential statistics, in which tables, graphs, charts, averages and percentages employed. For this study binary logit model has been used to see the relation between livelihood diversification and its determinants because of the dependent variable binary outcome in practice many researchers choose the binary logit model because of its comparative and mathematical simplicity [13].

\section{Results and Discusions}

\subsection{Demographic and Socio-economic Characteristics of Households}

As shown from Table 1 of the household head has a significant impact on household's ability of participation in nonfarm activity diversification. Female-headed HHs is most of the time more likely to be participated in nonfarm activity than male-headed households are. $51.2 \%$ of female-headed households diversified to nonfarm activity activities but only $36.3 \%$ of male HHs diversified to nonfarm activity income generational activities. The remaining male and female are not participate. From this figure, great differences were observed in the study area with regard to participation in nonfarm activity as far as sex of the household head was concerned. The association between participation in nonfarm activity and sex of household head was statistically significant at $\mathrm{p}<5 \%$. From the discussion held with key informants and focal groups female heads are more focus to nonfarm activity options because of they are not as effective as males in agriculture, have better opportunities in wage labor hence they paid lower than males and others. This finding is also true in other part of the country [6].

Education is one component to develop human capital. School education increases the human capital levels and provides the necessary skills, which enable the entry into more remunerative labor markets especially for nonfarm activity activities such as nonfarm activity wage labor or selfemployment [14]. With regard to the educational status of sample households $31.67 \%$ of the households in the study area were illiterate. So from the tableilliteracytook the priority in educational status $21.67 \%$ of the total respondents were able to read and write. Similarly, $29.16 \%$ of respondents were attained primary school education while only about $17.5 \%$ of the total households were attending secondary education. No any respondent that has completed higher education and those who complete high school is low as it shown from Table 1. The relationship between educational attainment of households head and participation in nonfarm activity, there is a positive relationship between the two variables. As it shown in the Table 1 , only $18.4 \%$ of illiterate households were participated in nonfarm activity while $38.5 \%$ of households who were able to read and write were participated in nonfarm activity. On the other hand, those households who attained primary education better participated in nonfarm activity $(45.7 \%)$ than illiterate households and those who can read and write. However, households who are attained secondary education were better participated in nonfarm activity (76.2\%) than the others were. Generally, the study shows that, households who are better in educational achievement were more likely to be participated in nonfarm activity than illiterate households were. Statistically the relationship between the two variables is significant at $1 \%$.

Number of family members in the house studied under the household characteristics. Family Size found as one of the determinant factors in the study area. Among the sample respondents $31.67 \%$ were those whose family sizes are below five, while those from 5-8 members of the family and above 8 members were counted $48.33 \%$ and $20 \%$, respectively. Most of the time households who had large family size were more likely to be participated in nonfarm activity than less household is size with limited labour [15]. The larger the family size, the better the households participation in diversification of livelihood activities as there can be more option of allocating labour force in to on-farm, off-farm and nonfarm activity. As it is shown in the Table 1 only $10.5 \%$ of the HHs diversified to nonfarm activity under the category of $<5$ members of the family. On the other hand $43.1 \%$ and $83.4 \%$ of households who had a family size of 5 to 8 and $>8$ respectively were participated in nonfarm activity. The study shows that, as the family size of the households increases, household's participation rate in nonfarm activity were also increase. Similarly the Pearson chi-square test shows that, the association between households participation in nonfarm activity and family size is statistically significant at $\mathrm{P}<0.01$.

The study reveals that, $24.2 \%$ of households in the study area were no own oxen, $38.3 \%$ has one ox, $26.7 \%$ has two oxen whereas the rest $10.8 \%$ of the households were owned 
greater than 2 oxen. From Table 1 it has shown that those who have two or more Oxen diversified more than others $(61.5 \%)$ have. However, the figure is still low. It is because of when a person has enough amounts of oxen sometimes it leads to renting land or engages in sharecroppingandprefers in expanding agricultural activities than doing nonfarm business. Next those who has no oxen diversified more than who has only one and two. $41.4 \%$ of ox less respondents diversified nonfarm activity. This is because of push factors mostly engage in wage employed nonfarm activity activities. These peoples have almost no option than migration or searching nonfarm activity option. Still those who has only one ox better diversified than who has two oxen. $39.1 \%$ of one-ox owners diversified into nonfarm activity where as $32 \%$ of two oxen owners diversified to nonfarm activity activities. Statistically the association of these two variables is not significant. In the Table 1oxen, ownership across different agro ecology is shown. The distribution is similar with sample kebeles. However, $40 \%$ of $\mathrm{HHs}$ in Yikgate Kebele has no oxen that are high with relative to GuayiandGoffichmaKebeles.

Lack of access to credit is the main constraints in developing countries [16]. Access to credit plays a crucial role in the decision to diversify $\mathrm{HH}$ income. Increase in access to credit by a given household will increase the level of nonfarm activity diversification. The reason is that the increase in the capital base will enable them to have enough resources to support members of the household. However, the figure still tells that majority of the households had access to credit services. According to the $\mathrm{HH}$ survey, the maximum amount of birr that a single HH get is 10000 birr. ACSI gives credit mainly for agricultural input purchase purpose but can also give for nonfarm activity business as the information got from the institution. Collateral is necessary to get the credit. Lack of collateral or guarantee makes the poor unable to get the credit access. Even the time for the repayment is short (one year) and many poor people fear to take the credit by the fear of unable to repay timely. When we see access, with regard to sex male households have better access than female-headed households in which $86.8 \%$ of male households have credit access but only $75.8 \%$ of the female households got access to credit according to the data shown below. Though Credit access is crucial for both female andmale-headed $\mathrm{HHs}$ female, headed $\mathrm{HHs}$ can enter to nonfarm activity activities with small financial capital. As discussed earlier females mostly engage in wage employment, which demands less finance.

Nonfarm income diversification and access to credit shows $84.2 \%$ of those respondents who got access of credit can diversify their nonfarm activity income. This result tells that credit has great role in diversifying the income of households. These households may not take the credit to run nonfarm activity business directly but indirectly it helps them to invest their own financial capital for nonfarm activity business. On the other hand, only $15.8 \%$ of respondents can run their nonfarm activity business without taking credit. Still $52.47 \%$ of those respondents who do not run nonfarm activity activities took credit from ACSI. Additionally 94.7\% of respondents, which cannot take credit, cannot also diversify nonfarm activity income. In general, the more the HHs gets credit access the better to diversify to nonfarm activity activities. Statistically access to credit is significant at $1 \%$.

Accordingly, the result of the study shows that, $22.5 \%$ of the studied households are rich, while the medium and poor constitute $42.5 \%$ and $35 \%$ respectively. When we see the relation between Participation in nonfarm activity activities and wealth, status there is a direct relation between them. Rich people enable to diversify $(70.3 \%)$ more than Medium people $(41.2 \%)$ and poor $(21.2 \%)$. The poorest rural groups probably have the fewest opportunities to diversify in a way that will lead to accumulation for investment purposes [17]. Wealth has a positive correlation with nonfarm activitydiversification, which implies that those rural poor who have not wealth previously (in Africa it is land holding or Livestock count) cannot employ in nonfarm activity activities [17]. The study undertaken in north shewa Ethiopia also show that the more resource a person has the more participate in nonfarm activity diversification [18].

Table 1. Demographic and Socio-economic Characteristics of Households.

\begin{tabular}{|c|c|c|c|c|c|c|c|c|}
\hline \multirow{3}{*}{ Variables } & \multirow{3}{*}{ Category } & \multicolumn{7}{|c|}{ Participation on non- farm activity } \\
\hline & & \multicolumn{2}{|c|}{ Participate } & \multicolumn{2}{|c|}{ Not participate } & \multicolumn{2}{|l|}{ Total } & \multirow{2}{*}{ Chi Test } \\
\hline & & Number & Percent & Number & Percent & Number & Percent & \\
\hline \multirow{3}{*}{ Age } & $<30$ & 11 & 27.5 & 29 & 72.5 & 40 & 33.3 & \multirow{3}{*}{2.75} \\
\hline & $30-45$ & 34 & 70.8 & 14 & 29.2 & 48 & 40 & \\
\hline & $>45$ & 4 & 12.5 & 28 & 87.5 & 32 & 26.7 & \\
\hline \multirow{2}{*}{ Sex } & Male & 33 & 36.3 & 58 & 63.7 & 91 & 75.83 & \multirow{2}{*}{$6.516^{* *}$} \\
\hline & Female & 16 & 51.2 & 13 & 44.8 & 29 & 24.17 & \\
\hline \multirow{4}{*}{ Educational Status } & Illiterate & 7 & 18.4 & 31 & 81.6 & 38 & 31.66 & \multirow{4}{*}{$2.69 * * *$} \\
\hline & read and write & 10 & 38.5 & 16 & 61.5 & 26 & 21.66 & \\
\hline & Complete Elementary & 16 & 45.7 & 19 & 54.3 & 35 & 29.16 & \\
\hline & Complete High School & 16 & 76.2 & 5 & 23.8 & 21 & 17.52 & \\
\hline \multirow{3}{*}{ Family size } & $<4$ & 4 & 10.5 & 34 & 89.5 & 38 & 31.66 & \multirow{3}{*}{$8.042 * * *$} \\
\hline & $4-8$ & 25 & 43.1 & 33 & 56.9 & 58 & 48.33 & \\
\hline & $>8$ & 20 & 83.4 & 4 & 10.6 & 24 & 20.01 & \\
\hline \multirow{3}{*}{ Land size (ha) } & $<1$ & 4 & 8.1 & 30 & 42.25 & 34 & 28.33 & \multirow{3}{*}{4.433} \\
\hline & $1-1.5$ & 10 & 20.4 & 30 & 42.25 & 40 & 33.33 & \\
\hline & above 1.5 & 35 & 71.4 & 11 & 15.49 & 46 & 38.34 & \\
\hline
\end{tabular}




\begin{tabular}{|c|c|c|c|c|c|c|c|c|}
\hline \multirow{3}{*}{ Variables } & \multirow{3}{*}{ Category } & \multicolumn{7}{|c|}{ Participation on non- farm activity } \\
\hline & & \multicolumn{2}{|c|}{ Participate } & \multicolumn{2}{|c|}{ Not participate } & \multicolumn{2}{|l|}{ Total } & \multirow{2}{*}{ Chi Test } \\
\hline & & Number & Percent & Number & Percent & Number & Percent & \\
\hline \multirow{3}{*}{ Number of Oxen } & No & 12 & 41.4 & 17 & 58.6 & 29 & 24.16 & \multirow{4}{*}{2.932} \\
\hline & Only 1 & 18 & 39.1 & 28 & 60.9 & 46 & 38.33 & \\
\hline & Has 2 & 11 & 34.4 & 21 & 65.6 & 32 & 26.66 & \\
\hline \multirow{3}{*}{ Access to Credit } & Above 2 & 8 & 61.5 & 5 & 38.5 & 13 & 10.85 & \\
\hline & has credit access & 48 & 47.53 & 53 & 52.47 & 101 & 84.16 & \multirow{2}{*}{$1.048 * * *$} \\
\hline & has no credit access & 1 & 5.3 & 18 & 94.7 & 19 & 15.84 & \\
\hline \multirow{3}{*}{ Wealth Status } & Rich & 19 & 70.3 & 8 & 29.7 & 27 & 22.5 & \multirow{3}{*}{1.32} \\
\hline & Medium & 21 & 41.2 & 30 & 58.8 & 51 & 42.5 & \\
\hline & Poor & 9 & 21.2 & 33 & 78.6 & 42 & 35 & \\
\hline
\end{tabular}

Source: Own Survey, 2018

\subsection{Status of Nonfarm Activity Activities in Deber Elias Woreda}

Studies have distinguished three livelihood strategies that the rural community engaged in as their source of means of subsistence. These include agricultural intensification, livelihoods diversification and migration. Nonfarm activity income diversification considered as one of the livelihood strategies in Deber Elias woreda. The status of nonfarm activity diversification participation stated below.

From table 2 result shows that $40.8 \%$ of sample households have participated in nonfarm activities while $59.2 \%$ did not engaged in any form of non-farm activity employment and their employment was mainly from farming and other sources like off farm activities and remittances. This figure shows participation in nonfarm activity in the study area is smaller when compared to some figures such as the country average $57.3 \%$ of the rural household participate in nonfarm activity activities [19].

Table 2. Participation in Nonfarm activity Activities in Deber Elias woreda.

\begin{tabular}{lll}
\hline Participation of households & Frequency & Percent \\
\hline Not participate in Nonfarm activity Activities & 71 & 59.2 \\
Participated in Nonfarm activity Activities & 49 & 40.8 \\
Total & 120 & 100.0 \\
\hline
\end{tabular}

Source: Own Survey, 2018

In general, self-employment activities were the dominant one in the area than wage employment, which accounts $48.5 \%$ of the participants as shown in Table 3. People who get hired on the other hand accounts $38.8 \%$ and those who created job by themselves and got hired are $12.5 \%$ of the total nonfarm activity participant. Unlike service delivery, income-generating activities in construction activities considered as wage employment activity. The nonfarm activity participants who get hired in construction and manufacturing counted $25.5 \%$. Most of the wage employment opportunities are mainly from road constructions done across rural kebeles, irrigation construction, home constructions of the dwellers, some institutions/offices construction (Classrooms, health post...) constructed by people, government and nongovernmental organizations are sources of nonfarm activity income by wage employment. In addition, people also do different casual activities in the nearby towns of Goffichma, Guye and Yikgate. Those laborers who have special skill like carpentry get paid more than unskilled laborers. The data from $\mathrm{HH}$ survey show that those people who have special skill has paid from birr 150 to 180 per day but the daily laborers hire only 40 birr per for females and 50 birr per day for males. There is a huge gap of income between skilled and unskilled laborers. Artesian are also another example. They took technical training by woreda water office and hire to develop different water scheme. As indicated above there is also a gap between males and females payment.

In general, the service sector plays great role in diversifying the income of rural poor beyond agricultural activities. In sample HH survey as indicated in Table 3, 58\% of people engaged in the service area. People engaged in Manufacturing and construction is $37 \%$. Mining is the third and last type of activities that people can diversify their income in nonfarm activityactivities, which accounts $5 \%$ in the above descriptive analysis.

Table 3. Percentages of People Participated In Nonfarm Activity Cross Tabulated In the Type of Employment and Activity.

\begin{tabular}{lllll}
\hline \multirow{2}{*}{ Type of Activity } & Type of Employment & & & Total \\
\cline { 2 - 5 } & Self-Employment & Wage Employment & Both self and Wage Employment & $58 \%$ \\
\hline Service & $38 \%$ & $12.5 \%$ & $7.5 \%$ & $37 \%$ \\
Manufacturing and Construction & $6.5 \%$ & $25.5 \%$ & $5 \%$ & $5 \%$ \\
Mining & $4.2 \%$ & $0.8 \%$ & $12.50 \%$ & 100 \\
Total & $48.50 \%$ & $38.80 \%$ & & \\
\hline
\end{tabular}

Source: Own Survey, 2018

\subsection{Causes of Nonfarm Activity Diversification in Deber Elias Woreda}

According to the household, survey both the pull and push factors enable farmers to engage in nonfarm activity diversification activities in Deber Elias Woreda. According to the household survey, $63 \%$ of the households diversify their income because of push factors. The dominant driving force 
in Deber Elias woreda is arising because of no or insufficient income earn from agricultural activities, this finding argument with the finding of $[20,21]$. From the total respondents $35 \%$ states push factors are the main motives behind their nonfarm activity diversification. Lack of enough farmland or no land owned as well as decreasing productivity of their farmland for their livelihood, inaccessibility of water for irrigation, Poor or no livestock production both in quality and in quantity is among the reason of nonfarm diversification. During the discussion held with FGD it can be understood that land distribution is held before 19 years ago in 1995 and the new generation has little access for land hereafter. These factors force the new generation to engage in nonfarm activity income generating activities. The other factor was the ability that other activities can compensate the inability of one dominant activity of the household to fulfill the need they want from that activity. Mostly this is done when the farmers lack some income to purchase Agricultural inputs they search for nonfarm activity income generational activities. According to the $\mathrm{HH}$ survey result $12 \%$ of respondents, engage in nonfarm activity to purchase agricultural inputs. The other driving force is to recover from risk or defend the forecasted upcoming risk. Risk mitigation replied by $7 \%$ of the sample $\mathrm{HHs}$ as driving force for nonfarm activity diversification. These activities practiced mainly to reduce the risk and uncertainty of agricultural sector. When a household is expecting that risk in front of them because of the scarcity of a kind of asset in their household, they most probably forced to engage in diverse livelihood to earn extra-income that will help their household to cope with the expected risk [22].

The data from the household survey shows that 37 percent of the sample households diversify their income because of pull factors. According to the survey the pull factors to diversify livelihoods are mainly because of the interest to use opportunities in their around including agricultural off season and wealth accomplishment. Farmers engaged in any nonfarm activity income generating activity based on their skill to utilize the opportunity their environment give them to produce extra income such as participate in mining or construction. Some of them use agricultural off-season to generate income from other nonfarm activity activities. Diversification to use the opportunity the other activities can generate income is also the other pull factor; some HHs for example bought animal cart for agricultural activities but can also gain income from the cart by renting or giving transportation service to others. $12 \%$ of HHs diversifies their income to utilize the opportunity in their area. The next important pull factors that make households engage in diverse livelihoods is the need for extra income or wealth accomplishment, which is one of the driving force to these people. Competition to wealth is commonly the factor that makes people to engage in nonfarm activity income generating options. Sample HHs respond diversify to nonfarm activity for the sake of wealth accomplishment encountered $15 \%$.

Cart service given by some people in the area is one of the symbols that clearly show the pull and push factor in the
Woreda. People in the area did this job because of both the pull and push factors. Those people who entered to the job due to lack of land or other pushing factors mainly did it as a full time job. On the other hand, households whose did as wealth creation did it when the burden of agricultural activities decreases or in the "holidays" such as Saturday. Otherwise, these people use the cart for home material transportation like agricultural products transportation from the farm to home or market. Some owners of the cart give the rental service or use it in share with those laborers.

Table 4. Percentage of household motive to diversify their income.

\begin{tabular}{ll}
\hline $\begin{array}{l}\text { Reason for not participating in to nonfarm } \\
\text { activity }\end{array}$ & \% of respondents motive \\
\hline Lack of sufficient HH income & 35 \\
Compensate the dominant activity(agriculture) & 12 \\
Reduce Risk & 7 \\
Utilize the opportunity in the area & 12 \\
Wealth accomplishment & 15 \\
Total & 100 \\
\hline
\end{tabular}

Source: Own Survey, 2018

\subsection{Frequency of Diversifying to Nonfarm Activity}

In Deber Elias Woreda people diversified their income and did these nonfarm activities as a full time job or as a part time activity. According to the discussion held with focal groups and key informants those who did nonfarm activity as a full time job are mostly enter because of the push factors. Those who participated in nonfarm activity activities because of having a piece of land, small no of oxen or lack of other agricultural resources did it throughout the year. Mostly the remaining members of the family do their agricultural activities. On the other hand, those who entered to the diversification because of pull factors mainly based on the annual agricultural activities. They gave high attention to agricultural activities. Therefore, they did not do nonfarm activity as a full time job rather does it as a secondary job. Because of their high interest in agricultural activities, from the figure 1 , only $27 \%$ of respondents did it throughout the year. The remaining $73 \%$ of the respondents replied that they did nonfarm activity in the way that does not compromise agricultural activities.

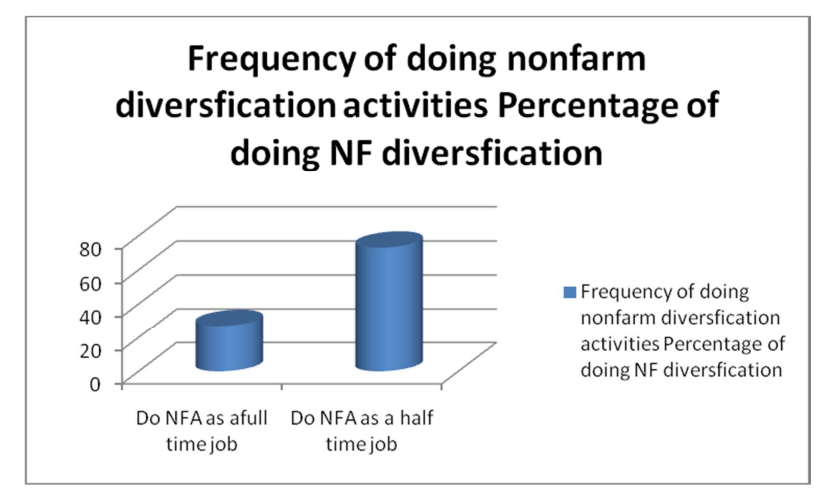

Source: Own Survey, 2018

Figure 1. Frequency of doing nonfarm activity diversification in Deber Elias woreda. 


\subsection{Determinants of Nonfarm Activity Income Generating Activities}

There are various factors, which affect participation decision of households in nonfarm activity, Binary logit model was used to see household's participation in nonfarm activity and the various independent variables which determine the household's participation decision to nonfarm activity. The results of binary logit model shows that, from the seven explanatory variables that are included in the model, five of them are found to be the main determinants of household's nonfarm activity participation.

Table 5. Binary logit model result.

\begin{tabular}{lllllll}
\hline Variable & B & S.E. & Wald & Df & Sig. & Exp (B) \\
\hline Age & 0.406 & 0.412 & 0.975 & 1 & 0.323 & 1.501 \\
Education & 1.083 & 0.292 & 13.737 & 1 & $.001^{* * *}$ & 2.953 \\
Land & 1.768 & 0.458 & 14.896 & 1 & $.001^{* * *}$ & 5.859 \\
Sex(male) & 1.726 & 0.689 & 6.275 & 1 & $.012^{* * *}$ & -5.619 \\
Fam Size & 1.754 & 0.469 & 14.005 & 1 & $.001^{* * *}$ & 5.777 \\
Oxen & 0.004 & 0.307 & 0 & 1 & 0.989 & 1.004 \\
Credit & 1.984 & 0.999 & 3.943 & 1 & $.047^{* *}$ & 7.271 \\
Constant & -14.97 & 3.05 & 24.044 & 1 & 0 & 0 \\
\hline
\end{tabular}

Source: Own Survey, 2018

Sex of household head: as shown From the Table there is negative relationship between participation in nonfarm activity and sex of households and the relationship are significant at $<0.05$. Being Femaleness HHs would increase the likelihood of household participation in nonfarm activity by a factor of 5.619. This study argument withWomen play an important role in generating non-farm income [23] and also women earn more share of nonfarm activity than male headed $\mathrm{HH}$ [22].

Family size: family size is also one of the major factors which determine household's participation decision in nonfarm activity diversification activities. Most of the time households who have large family size were more likely to be participated in nonfarm activity than less household is size with limited labour [24]. Family size also one of the determinant factors which have a significant impact on household's participation in diverse livelihood activities. The relationship between family size and participation in different livelihood activity is statistically significant at significance level of $<0.01 \%$. The result of the study shows that an addition of a one individual in households will increase the likelihood of household's participation in nonfarm activity by a factor of 5.77. Those households who have rich labor resources had found to be more likely to be participated in nonfarm activity than labor poor family. Because, households with large family size have a better chance to allocate their labor force in to different farm and nonfarm activity ventures.

Access to Credit: getting credit is a strong relationship between nonfarm activity diversification and household access to credit. The relation between the two variables is statistically significant at $\mathrm{p}<0.05$ level. The probability of participating in nonfarm activity is high for households who got access to credit. Those households who took credit from the only supplier in the area that is ACSI found more participate in nonfarm activity diversification event than those who cannot took the credit because of lack of collateral and other reasons. Having access to credit would increase the likelihood of participating in nonfarm activity by a factor of 7.271. This study in line with Sanusi et., al, [25] Effects of Non-Farm Income on Household Welfare with credit access.

Educational level of household head: Educational level of household head is one of the major determinant factors in the area that to diversify $\mathrm{HH}$ income. HHs who attends better education also had better participate in nonfarm activity diversification activities in the study area. Ellis [21] state educational attainment as one of the major factor which affects rural household's participation in nonfarm activity. The relationship between the two variables is statistically significant at $\mathrm{p}<0.01 \%$. As education increases by one years of schooling, the likelihood of household participation in nonfarm activity by a factor of 5.859

Land Size: Land Size of household head is also found to be one of the main factors which affect the household's participation in nonfarm activity. In the study area, land is the major symbol of wealth status and from the previous, this means rich people have more access to start nonfarm activity income generating activities. There is a direct relationship between land ownership and nonfarm activity diversification. The relationship between the two variables is statistically significant at $\mathrm{p}<0.01 \%$. Then HHs who have large land size, have large nonfarm activity.

\section{Conclusion and Recommendations}

In order to lift up the deprived and poor society as well as keep sustainability of growth of the Country, the rate of rural nonfarm activity should improve. Thus, to encourage people involve in Non-farm activities are to supplement or replace agricultural income and to enable poor household overcome credit constrains. Rural farmers in the village different factors institutional, economic, cultural and social factors should be considered. Precisely, ultimate effort has to be made to raise the income level of rural dwellers in a sustainable manner and different income diversification strategy should be devised. Providing access to credit, educational facilities, improving the living condition of rural households should be given due attention from governmental and nongovernmental organizations.

The result of the model indicated that male headed household, education, family size, access to credit; Educational level of household head and land size had statistically significant positive effect on households' level of income diversification. This implies that the above variables increase the level of determinants of household's nonfarm activity participation. To increasing the extent of income diversification, government should continue its efforts to generate income earning opportunities in the rural areas and support the farmers to enhance agricultural productivity through supportive policies including input utilization and creating market for their product. Government and other 
responsible bodies design necessary strategies so as to create awareness among the community to participate women equally with man in all development activities. The concerned body has to work more to increase the access to education in the study area in order to explore the existing opportunity of income diversification via non-farm activities. Moreover, community based health and nutrition related education should be strengthened through direct educational support as well as awareness raising programmes.

\section{References}

[1] Agency., C. C. I., The work of a nation, Ethiopian economy profile 2018. CIA world fact book, January 20, 2018. 2018.

[2] Ellis, F., Rural livelihoods, diversity and poverty reduction policies: Uganda, Tanzania, Malawi and Kenya. 2001: University of East Anglia.

[3] Lyson, T. A., Civic agriculture: Reconnecting farm, food, and community. 2012: UPNE.

[4] Dimova, R. D. and K. Sen, Is household income diversification a means of survival or a means of accumulation? Panel data evidence from Tanzania. Panel Data Evidence from Tanzania (April 6, 2010), 2010.

[5] Ellis, F., Household strategies and rural livelihood diversification. The journal of development studies, 1998. 35 (1): p. $1-38$

[6] Demissie, A. and B. Legesse, Determinants of income diversification among rural households: The case of smallholder farmers in Fedis district, Eastern hararghe zone, Ethiopia. Journal of Development and Agricultural Economics, 2013. 5 (3): p. 120-128.

[7] Kilic, T., et al., Rural nonfarm income and its impact on agriculture: evidence from Albania. Agricultural Economics, 2009. 40 (2): p. 139-160.

[8] Ahmed, B., What Factors Contribute to the Smallholder Farmers Farm Income Differential'Evidence from East Hararghe, Oromia, Ethiopia. Journal of Asian Scientific Research, 2016. 6 (7): p. 112.

[9] Zerai, B. and Z. Gebreegziabher, Effect of nonfarm income on household food security in eastern Tigrai, Ethiopia: An entitlement approach. Food Science and Quality Management, 2011. 1: p. 1-22.

[10] Olale, E. and S. Henson, Determinants of income diversification among fishing communities in Western Kenya. Fisheries Research, 2012. 125: p. 235-242.

[11] Yizengaw, B., Determinants of household income diversification and its effect on food security status in rural Ethiopia: Evidence from Ethiopia longitudinal rural household survey. 2014, MSc Thesis, Addis Ababa University, Addis Ababa, Ethiopia.
[12] Melaku, A. and A. Abebe, Bovine Trypanosomosis and Its Vector Type and Density at Debre Elias District, Northwestern, Ethiopia. Journal of Advanced Veterinary Research, 2012. 2 (4): p. 247-251.

[13] Gujarati, D. N., Basic econometrics. 2009: Tata McGraw-Hill Education.

[14] Lanjouw, P. and A. Shariff, Rural non-farm employment in India: Access, incomes and poverty impact. Economic and Political Weekly, 2004: p. 4429-4446.

[15] Mohamed, S. and D. Haji, Impact of Productive Safety Net Program on Household Food Security and Asset Building: The Case of Goro Gutu District, East Hararghe Zone of Oromia National Regional State, Ethiopia. 2017, Haramaya University.

[16] Weir, S., The effects of education on farmer productivity in rural Ethiopia. The Centre for the Study of African Economies Working Paper Series, 1999: p. 91.

[17] Barrett C. B., R. T. a. W. P., Nonfarm activity income diversification and household livelihood strategies in rural Africa: concepts, dynamics, and policy implications:. 2001.: p. pp1-31.

[18] Uraguchi, Z. B. Social protection for redistributive justice: socio-economic and political drivers of vulnerability to food insecurity in Bangladesh and Ethiopia. in International Conference on Social Protection for Social Justice. UK: Institute of Development Studies. 2011.

[19] AbebeDamte., Farm Households Labor supply to off farm activities in Ethiopia. MA thesis, Addis Ababa University, Ethiopia,. 2002.: p. 108 pp.

[20] Reardon, T., Using evidence of household income diversification to inform study of the rural nonfarm labor market in Africa. World development, 1997. 25 (5): p. 735747.

[21] Ellis, F., The determinants of rural livelihood diversification in developing countries. Journal of agricultural economics, 2000. 51 (2): p. 289-302.

[22] DerejeBeyene., Livelihood Diversification as a strategy to overcome food insecurity in Ethiopia: A case study of smallholder farmers in Bako-TibeWoreda. MA thesis, Addis Ababa University, Ethiopia,. 2010: p. 92 pp.

[23] Paavola, J., Livelihoods, vulnerability and adaptation to climate change in Morogoro, Tanzania. Environmental Science \& Policy, 2008. 11 (7): p. 642-654.

[24] Muse., A., Diversification of Livelihood Activities as a strategy of promoting food Security a case of DaroLebuWoreda of West Hararghe, Oromia Regional State. MCs thesis, Addis Ababa University, Ethiopia,. 2011: p. 91 pp.

[25] Akinyemi, M., Effects of Non-Farm Income on Household Welfare in Osun State of Nigeria. 